This is an electronic reprint of the original article. This reprint may differ from the original in pagination and typographic detail.

Author(s): Amin, Vikesh; Böckerman, Petri; Viinikainen, Jutta; Smart, Melissa C.; Bao, Yanchun; Kumari, Meena; Pitkänen, Niina; Lehtimäki, Terho; Raitakari, Olli; Pehkonen, Jaakko

Title: Gene-environment interactions between education and body mass : Evidence from the UK and Finland

Year: $\quad 2017$

Version:

Please cite the original version:

Amin, V., Böckerman, P., Viinikainen, J., Smart, M. C., Bao, Y., Kumari, M., Pitkänen, N., Lehtimäki, T., Raitakari, O., \& Pehkonen, J. (2017). Gene-environment interactions between education and body mass : Evidence from the UK and Finland. Social Science and Medicine, 195, 12-16. https://doi.org/10.1016/j.socscimed.2017.10.027

All material supplied via JYX is protected by copyright and other intellectual property rights, and duplication or sale of all or part of any of the repository collections is not permitted, except that material may be duplicated by you for your research use or educational purposes in electronic or print form. You must obtain permission for any other use. Electronic or print copies may not be offered, whether for sale or otherwise to anyone who is not an authorised user. 


\title{
Gene-Environment Interactions Between Education and Body Mass: Evidence from the UK and Finland
}

\begin{abstract}
More education is associated with a lower body mass index (BMI) and likelihood of being overweight. However, given that a large proportion of the variation in body mass is due to genetic makeup, it has been hypothesized that education may moderate the genetic risk. We estimate main associations between (i) education, (ii) genetic risk, and (iii) interactions between education and genetic risk on $\mathrm{BMI}$ and the probability of being overweight in the UK and Finland. The estimates show that education is negatively associated with BMI and overweightness, and genetic risk is positively associated. However, the interactions between education and genetic risk are small and statistically insignificant.
\end{abstract}

Key words: education; gene-environment interactions; obesity 


\section{Introduction}

Tackling obesity is a major public health issue because of the high prevalence and associated costs. In $2014,39 \%$ of adults were overweight, and $13 \%$ were obese globally (WHO 2016). If the current trends continue, it is estimated that $50 \%$ of adults worldwide

will be overweight or obese by 2030 (Dobbs et al. 2014). The global economic impact of obesity is estimated to be $\$ 2$ trillion, making it one of the largest social burdens (Dobbs et al. 2014).

Obesity is a complex condition. It is the result of interplay between one's behavior, environment and genetic makeup. While there are many environmental, socioeconomic and behavioral factors that are associated with obesity, from 6 to 85 percent of the variation in obesity can be attributed to genes (Yang et al. 2007). A genome wide association study (GWAS) by Speliotes et al. (2010) identified 32 single nucleotide polymorphisms (SNPs) as significant predictors of body mass index (BMI). These SNPs explain $1.45 \%$ of the variation in BMI.

Education is strongly positively correlated with health outcomes. Education has also been advocated as a protective factor against obesity (Link \& Phlean 1995). Higher education can lower the likelihood of being obese because education increases resources enabling purchase of better health care; promotes interactions with other more educated peers generating positive health spillovers; changes preferences, norms and behaviors related to health; increases access to and use of information in making health-related decisions. While there are many studies that estimate main effects of education on body mass (Brunello et al. 2013; Kemptner et al. 2011; Webbink et al. 2010; Böckerman et al. 2017), this paper considers whether education moderates the genetic risk, through gene- 
environment (GXE) interactions, which occur when the effect of genetic risk varies across the environment.

Within the GxE framework there are different models to explain why environmental and behavioral factors moderate genetic predisposition. The diathesis-stress model (Ellis et al. 2011) hypothesizes that unhealthy environments (low education) trigger risk allele effects, while healthy environments (high education) protect against the effects of risk alleles. A college graduate with a high genetic risk of being obese may never be obese because education is associated with higher income affording the individual to eat healthier and having peers who are conscience about leading a healthy lifestyle. In contrast, a high school dropout with a high genetic risk is more likely to be obese because he/she has a low income, is more likely to consume fast food, and has peers who are also obese. The differential susceptibility model (Belsky \& Pluess 2009) hypothesizes that some individuals are "dandelions", meaning they have a genetic makeup that is unaffected by both positive and negative environments. Others are "orchids" whose genetic makeup is highly sensitive to the environment. These individuals thrive in positive environments but wilt in negative environments.

Only a few studies have investigated GxE interactions between education and BMI. Liu et al. (2015) use a sample of elderly non-Hispanic whites from the Health and Retirement Study to estimate the interaction between education and a genetic risk score (GRS) for BMI based on the GWAS by Speliotes et al. (2010). They find no significant interaction between education and the GRS. Liu and Guo (2015) use the same dataset, but interact the GRS with measures of socioeconomic status (SES) throughout the lifecourse. They use measures of SES in childhood (father's occupation), young adulthood 
(years of education) and middle/late adulthood (household wealth). There is no statistically significant interaction between childhood SES and GRS. However, the genetic influence on BMI is greater for individuals who experienced less socioeconomic advantage than those who experienced more socioeconomic advantage over the lifecourse. Tyrrell et al. (2017) find no significant interaction between education and a GRS for BMI based on 69 SNPs (Locke et al. 2015) in a sample of 118,775 individuals from the UK Biobank. A concurrent study by Komulainen et al. (2017) uses the longitudinal aspect of the Young Finns Study, and finds a significant negative interaction between education and a GRS for BMI based on 97 SNPs.

We contribute by comparing and contrasting results of GxE interaction models between the GRS of BMI (based on the GWAS by Speliotes et al. (2010) and Locke et al. (2015)) and education in the UK and Finland. There are useful differences between the UK and Finland, which are relevant to the detection of GxE interactions. First, the prevalence of obesity and the proportion of individuals without upper secondary education is lower in Finland than in the UK. According to OECD figures, in $201451.2 \%$ (61.7\%) of the population over age 15 were overweight/obese in Finland (the UK), and $13.49 \%$ (20.8\%) of adults aged $25-64$ did not complete upper secondary education. Thus, individuals in Finland are likely to have more educated peers, mitigating the effect of genes on obesity. Second, Finland is a prominent example of a Nordic welfare state that has universal social security and health care system. Social insurance mitigates the effects of SES on health outcomes. Additionally, income inequality is much lower in Finland compared to the UK. These differences are relevant for GxE interactions, 
because high income inequality may predispose individuals to the negative effects of genetic variants on health.

\section{Data}

\subsection{Understanding Society: UK Household Longitudinal Study (UKHLS)}

The UKHLS is a large panel dataset of households and individuals, which started in 2009. It consists of a general population sample of 40,000 households $(100,000$ individuals) and households from the British Household Panel Study, which began in 1991. The annual questionnaire collects information on a range of topics including family background, education, and health. In wave 2, a nurse interview was conducted where physical measurements such as blood pressure, height and weight were taken. Also, blood and DNA samples were taken. Out of an eligible sample of 35,563 respondents, 13,571 consented to provide blood and DNA samples. DNA genotyping was performed by the Sanger Institute using the Illumina HumancoreExom chip for approximately 10,500 respondents of white European descent.

Our analytical sample consist of 8,305 white individuals aged 25-99, who had valid information on height, weight, education and SNPs used to construct the GRS. An unweighted GRS was constructed based on 31 of the 32 SNPs that were found to be associated genome-wide significantly $\left(p<1.0 \times 10^{-8}\right)$ with BMI in Speliotes et al. (2010). We also construct an unweighted GRS based on 71 SNPs that were found to be associated genome-wide significance with BMI in Locke et al. (2015). Body mass is measured using BMI (weight in $\mathrm{kg} /$ height $\mathrm{m}^{2}$ ), and using an indicator variable for being overweight (BMI $\geq 25)$. Respondents were asked to report their highest qualification. We create indicator variables for having attained (i) university education, (ii) post-compulsory 
education (A-levels, other higher degree), (iii) compulsory education (GCSE) and (iv) lower than compulsory education (other qualification, no qualification).

\subsection{The Young Finns Survey (YFS)}

The YFS began in 1980 to examine contributors to the risk of cardiovascular diseases. Subjects in six age cohorts (aged 3, 6, 9, 12, 15 and 18 years) were randomly chosen from the five university hospital districts of Finland using the national population register (Raitakari et al. 2008). The original sample size is 3,596 persons. In 2009, genotyping was performed using the $670 \mathrm{~K}$ Illumina platform (Sanger Institute, UK). After quality control, there were more than 546 thousand genotyped single SNPs available in 2,442 YFS participants for further analysis. Imputation for up to 2.5 million SNPs was performed using information on Hapmap 2 by using MACH.5. All the SNPs were imputed with excellent imputation quality (MACH $r 2>0.8$ ). The GRS is equal to the sum of the alleles associated with higher BMI in all of the 32 SNPs in Speliotes et al. (2010).

BMI was measured in 2001, when the participants were between 24 and 39 years old. Height and weight measures for the BMI were collected in professional health examinations at local health centres. To obtain information on education, the YFS was linked to the Finnish Longitudinal Employer-Employee data of Statistics Finland using unique personal identifiers. Register information on the highest completed degrees in 2001 was converted to indicator variables for having obtained (i) university education, (ii) post-secondary non-tertiary or short-cycle tertiary education or (iii) compulsory or upper secondary education. 


\section{Methodology}

We estimate main associations of education, genetic risk and GxE interactions through OLS regressions for equation (1) where the $\mathrm{BMI}$ of individual $\mathrm{i}\left(\mathrm{BMI} \mathrm{i}_{\mathrm{i}}\right)$ is related to the genetic risk score $\left(G R S_{i}\right)$, education attainment $\left(E D_{i}\right)$, an interaction between genetic risk and education attainment $\left(G R S_{i}^{*} E D_{i}\right)$, a vector of control variables $\left(X_{i}\right)$ and an error term (ui).

$$
\mathrm{BMl}_{\mathrm{i}}=\mathrm{b}_{0}+\mathrm{b}_{1} \mathrm{GRS}_{\mathrm{i}}+\mathrm{b}_{2} \mathrm{ED}_{\mathrm{i}}+\mathrm{b}_{3}\left(\mathrm{GRS}_{\mathrm{i}}{ }^{*} E D_{i}\right)+\mathrm{y}^{\prime} \mathrm{X}_{\mathrm{i}}+u_{i}
$$

The key parameter is $b_{3}$, which measures the marginal association of the GRS for different levels of educational attainment. If education moderates the genetic risk, then the interaction will be negative.

\section{Results}

The average age in the UKHLS (YFS) is 54.30 (31.71), and in both datasets over half the individuals (55\%) are female (Table 1). In terms of educational attainment, the proportion of individuals with a university education is similar in both datasets $(\sim 20 \%)$. The main difference in educational attainment relates to compulsory education. In the UKHLS $21 \%$ of individuals have attained compulsory education, whereas $58 \%$ of individuals in the YFS have attained compulsory or upper secondary education. The unweighted GRS is similar in both datasets, with an individual having on average 30 risk alleles. The GRSs are normally distributed (Supplementary Figure A1). Average BMI is similar in both datasets, but the proportion of individuals who are overweight is substantially higher in the UKHLS $(72 \%)$ than in the YFS $(44 \%)$.

Panel A in Table 2 presents main results for the UKHLS using the GRS based on Speliotes et al. (2010). All regressions control for age, gender, and interview year. The 
GRS has been standardized to have a mean of 0 and standard deviation (SD) of 1 . Column 1 shows that a one SD increase in the GRS is associated with $0.513 \mathrm{~kg} / \mathrm{m}^{2}$ units increase in BMI, and it explains $2.2 \%$ of the variation in BMI. Column 2 adds educational attainment indicators, and shows that the negative association between education and $\mathrm{BMI}$ is much larger at upper end of the educational distribution. The average difference in BMI between individuals who have a university education and those who have less than compulsory education is $1.671 \mathrm{~kg} / \mathrm{m}^{2}$ units. In comparison, the average difference in BMI between individuals with some post compulsory education and those who have less than compulsory education is less than half the magnitude $\left(0.683 \mathrm{~kg} / \mathrm{m}^{2}\right.$ units $)$. Column 3 adds interactions between the GRS and educational attainment indicators. While the GRS and education are still significantly associated with BMI, the interaction estimates are small and statistically insignificant. Columns 4-6 provide estimates for the probability of being overweight. Column 5 shows that a one SD increase in the GRS increases the probability of being overweight by 3.1 percentage points, and individuals with a university education are 9.8 percentage points less likely to be overweight than those with less than compulsory education. The GxE interaction estimates in column 6 though are small and statistically insignificant.

A power analysis indicates that the sample size is sufficient to detect significant GxE interactions. For example, to detect an effect size of 0.02 with $95 \%$ power, 10 predictors (main association of GRS, 3 education indicators, 3 GxE terms and controls for age, gender, interview year), and testing 3 interaction terms requires a sample size of 1,062 , based on a Bonferroni adjusted alpha of 0.016 . If one applies a more stringent alpha of $10^{-6}$, the required sample size increases to 2,481 . Although the sample size is 
large enough, it is possible that the insignificant GxE estimates are due poor explanatory power of the GRS. The GRS based on Speliotes et al. (2010) only explains $2.2 \%$ of the variation in BMI in the UKHLS. Panel B in Table 2 shows results using an unweighted GRS based on the GWAS by Locke et al. (2015), which has more predictive power than the GRS in Panel A. This is evident as the main association of genetic risk is larger in Panel B than in Panel A. Column 1 (4) shows that a 1 SD increase in the GRS in Panel B increases BMI (the probability of being overweight) by $0.603 \mathrm{~kg} / \mathrm{m}^{2}(3.2$ percentage points), and it explains $2.7 \%(3.3 \%)$ of the variation in BMl (probability of being overweight). Despite stronger main associations of genetic risk and body mass, the GxE terms are small and insignificant, like in Panel A.

Results for the YFS are given in Table 3, where the omitted educational attainment category is compulsory or upper secondary education. The estimates in columns 3 and 6 , lead to the same conclusion as in the UKHLS. There are strong main associations between genetic predisposition and BMI/overweightness. A 1 SD increase in the GRS increases BMI (probability of being overweight) by $0.597 \mathrm{~kg} / \mathrm{m}^{2}$ units (5 percentage points). However, despite these strong main associations, the interactions between the GRS and educational attainment indicators are small and insignificant.

The results for the UKHLS and YFS are not directly comparable. The UKHLS results are based on individuals aged 25-99, whereas the YFS results are based on individuals aged 24-39. The conclusions did not change when we restricted the UKHLS to individuals aged 25-39 (supplementary Table A1), or when we used an indicator for being obese $(\mathrm{BMI} \geq 30)$ (supplementary Table $A 2)$. However, there was a significant $\mathrm{GxE}$ interaction in the YFS when using an obesity indicator. Individuals with post-secondary 
education had 4 percentage point lower probability of being obese compared to their less educated counterparts (supplementary table A3). We also found some indication of gender differences in the UKHLS, with significant GxE interactions estimates for men (women) for BMI (likelihood of being overweight). The association between the Locke et al. (2015) GRS and BMI (likelihood of being overweight) for men (women) with a university education in the UKHLS was $0.421 \mathrm{~kg} / \mathrm{m}^{2}$ units (4.8 percentage points) lower compared to men (women) without compulsory education (supplementary Table A4). There was no evidence of any gender differences in the YFS (supplementary Table A5), although the sample size was substantially smaller.

\section{Summary}

We estimate GxE interaction models between the GRS of BMI and education in the UK and Finland, using data from the UKHLS and YFS datasets. To our knowledge, there are no earlier studies that contrast two countries in this setting. There are differences in the proportion of individuals without compulsory education and social welfare systems between Finland and the UK. For Finland and the UK individually we find significant main associations of education and genetic risk, but no statistically significant evidence for the existence of GxE interactions. However, we are not able to make definite conclusions about the potential cross-country differences in the estimated effects owing to the relatively small sample sizes.

The null results for the UK are consistent with those from Tyrell et al. (2017) who also find insignificant GxE interaction estimates using a large sample of 118,775 individuals from the UK Biobank. However, we found some significant GxE interactions in the UKHLS, which are suggestive of gender differences. The results for Finland differ 
from a concurrent by Komulainen et al. (2017). They examine the issue using the longitudinal aspect of the YFS with a GRS for BMI, and find that education accentuates the genetic risk for higher BMI. There are two major differences between the studies. Komulainen et al. (2017) use a GRS based on 97 SNPs, and longitudinal variation in selfreported educational attainment. We use a GRS based on 32 SNPs, and cross-sectional variation in educational attainment based on register data. Although the GRS used in Komulainen et al. (2017) has more predictive power than the GRS employed in this study, we believe our treatment of educational attainment is preferred for three reasons. First, register-based data on educational attainment contains less (classical) measurement error than self-reported education, which attenuates GxE estimates. Second, Komulainen et al. (2017) use years of education, which constrains the marginal effect of education to be constant. We use indicators for highest educational attainment as there are sheepskin effects in the returns to education. Third, there is not much relevant longitudinal variation in educational attainment. Table 1 in Komulainen et al. (2017) shows the proportion of individuals with a bachelors degree in 2001 (2007) was 13.5\% (19.9\%).

This study has important limitations. First, the datasets have relative small sample sizes. The GRS only explains a small proportion of the variation in BMI. Thus, the insignificant GxE estimates may be due to a lack of explanatory power. The GRS is a robust predictor of mean levels of BMI, as it is obtained from meta-analyses of studies that span a wide range of (Western) countries and cohorts. However, the failure to detect GxE interactions may be because the GRS captures level effects that are common across environments rather than genetic influences that are context specific (Conley 2017). Second, our results do not represent causal effects because education (and therefore the 
GxE interactions) is likely to be correlated with the error term. The correlation could arise because of (i) unobserved factors such as time preference, health endowments that affect education and BMI, (ii) reverse causality or (iii) genes affect education. More research is definitely needed to identify the causal GxE interactions in cross-country settings. 


\section{References}

Belsky, J., Pluess, M. 2009. Beyond diathesis stress: Differential susceptibility to environmental influences. Psychological Bulletin, 135(6), 885-908.

Böckerman, P., Viinikainen, J., Pulkki-Råback, L., et al. 2017. Does higher education protect against obesity? Evidence using Mendelian randomization. Preventive Medicine, 101, 195-198.

Brunello, G., Fabbri, D., Fort, M. 2013. The causal effect of education on body mass: Evidence from Europe. Journal of Labor Economics, 31(1), 195-223.

Conley, D. 2017. The challenges of GxE: Commentary on "Genetic endowments, parental resources and adult health: Evidence from the Young Finns Study". Social Science and Medicine, 188, 201.

Dobbs, R., Sawers, C., Thompson, F., et al. 2014. Overcoming Obesity: An initial Economic Analysis. Mckinsey Global Institute Discussion Paper.

Ellis, B.J., Boyce, W.T., Belsky, T., et al. 2011. Differential susceptibility to the environment: An evolutionary-neurodevelopmental theory. Development and Psychopathology, 23(01), 7-28 
Kemptner, D., Jürges, H., Reinhold, S. 2011. Changes in compulsory schooling and the causal effect of education on health: Evidence from Germany. Journal of Health Economics, 30(2), 340-354.

Komulainen, K., Pulkki-Råback, L., Jokela, M., et al. 2017. Education as a moderator of genetic risk for higher body mass index: Prospective cohort study from childhood to adulthood. International Journal of Obesity, Forthcoming. doi:10.1038/ijo.2017.174

Link, B.G., Phelan, J.1995. Social conditions as fundamental causes of disease. Journal of Health and Social Behavior, Extra issue: Forty Years of Medical Sociology: The State of the Art and Directions for the Future, 80-94.

Liu, H., Guo, G. 2015. Lifetime socioeconomic status, historical context, and genetic inheritance in shaping body mass in middle and late adulthood. American Sociological Review, 80(4), 705-737

Liu, S.Y., Walter, S., Marden, J., et al. 2015. Genetic vulnerability to diabetes and obesity: Does education offset the risk? Social Science and Medicine, 127, 150-158.

Locke, A.E., Kahali, B., Berndt, S.I., et al. 2015. Genetic studies of body mass index yield new insights for obesity biology. Nature, 518(7538), 197-206.

OECD. 2017. Obesity Update. www.oecd.org/health/obesity-update.htm 
OECD. 2016. Education at a Glance 2016. www.oecd.org/edu/eag.htm

Raitakari, O.T., Juonala, M., Rönnemaa, T., et al. 2008. Cohort profile: The cardiovascular risk in Young Finns Study. International Journal of Epidemiology, 37, $1220-1226$.

Speliotes, E.K., Willer, C.J., Berndt, S.I., et al. 2010. Association analyses of 249,796 individuals reveal 18 new loci associated with body mass index. Nature Genetics, 42(11), 937-948.

Tyrrell, J., Wood, R., Ames, R.M., et al. 2017. Gene-obesogenic environment interactions in the UK Biobank study. International Journal of Epidemiology, 46(2)1-17.

Webbink, D., Martin, N.G., Visscher, P.M. 2010. Does education reduce the probability of being overweight? Journal of Health Economics, 29(1), 29-38.

Yang, W., T. Kelly, He, J. 2007. Genetic epidemiology of obesity. Epidemiologic Reviews, 29(1), 49-61.

WHO

2016.

Obesity

and

overweight

factsheet. www.who.int/mediacentre/factsheets/fs311/en. 
Table 1: Summary Statistics

\begin{tabular}{lll}
\hline & UKHLS & YFS \\
\hline Age & $54.30(15.15)$ & $31.71(4.98)$ \\
Female & $0.56(0.50)$ & $0.55(0.50)$ \\
Education & & \\
$\quad$ Less than compulsory & $0.26(0.44)$ & --- \\
$\quad$ Compulsory & $0.21(0.40)$ & --- \\
$\quad \begin{array}{l}\text { Compulsory or upper } \\
\text { secondary }\end{array}$ & -- & $0.58(0.49)$ \\
$\quad \begin{array}{l}\text { Post-compulsory } \\
\quad \text { Post-secondary }\end{array}$ & $---31(0.46)$ & -- \\
$\quad$ University & $0.21(0.41)$ & $0.20(0.40)$ \\
BMI & $28.07(4.91)$ & $0.22(0.42)$ \\
Overweight & $0.72(0.44)$ & $25.07(4.32)$ \\
GRS & $30.08(3.42)$ & $0.44(0.50)$ \\
$\mathrm{N}$ & 8,305 & $29.15(3.36)$ \\
\hline
\end{tabular}

Notes: Standard deviations in parentheses. 
Table 2: OLS estimates of main associations of education, genetic risk, and GXE interactions in the UKHLS

\begin{tabular}{|c|c|c|c|c|c|c|}
\hline & $\begin{array}{l}\text { BMI } \\
(1)\end{array}$ & $\begin{array}{c}\text { BMI } \\
(2)\end{array}$ & $\begin{array}{l}\text { BMI } \\
(3)\end{array}$ & $\begin{array}{l}\text { Overweight } \\
\text { (4) }\end{array}$ & $\begin{array}{l}\text { Overweight } \\
\text { (5) }\end{array}$ & $\begin{array}{l}\text { Overweight } \\
\text { (6) }\end{array}$ \\
\hline \multicolumn{7}{|l|}{$\begin{array}{l}\text { Panel A: GRS based on } \\
\text { Speilotes et al. (2010) }\end{array}$} \\
\hline GRS & $\begin{array}{l}0.513 \\
(.053)^{\star * *}\end{array}$ & $\begin{array}{l}0.505 \\
(.053)^{\star * \star}\end{array}$ & $\begin{array}{l}0.490 \\
(.101)^{\star * *}\end{array}$ & $\begin{array}{l}0.032 \\
(.005)^{* * *}\end{array}$ & $\begin{array}{l}0.031 \\
(.011)^{* * *}\end{array}$ & $\begin{array}{l}0.027 \\
(.009)^{\star * *}\end{array}$ \\
\hline \multicolumn{7}{|l|}{ Educational Attainment } \\
\hline Compulsory & -- & $\begin{array}{l}-0.453 \\
(.105)^{\star * *}\end{array}$ & $\begin{array}{l}-0.453 \\
(.165)^{\star * *}\end{array}$ & --- & $\begin{array}{l}-0.012 \\
(.014)\end{array}$ & $\begin{array}{l}-0.012 \\
(.015)\end{array}$ \\
\hline Post Compulsory & --- & $\begin{array}{l}-0.683 \\
(.150)^{\star * *}\end{array}$ & $\begin{array}{l}-0.683 \\
(.149)^{\star * *}\end{array}$ & --- & $\begin{array}{l}-0.034 \\
(.013)^{\star \star \star}\end{array}$ & $\begin{array}{l}-0.034 \\
(.013)^{\star * *}\end{array}$ \\
\hline University & --- & $\begin{array}{l}-1.671 \\
(.162)^{\star \star *}\end{array}$ & $\begin{array}{l}-1.671 \\
(.162)^{\star * *}\end{array}$ & --- & $\begin{array}{l}-0.098 \\
(.015)^{\star * *}\end{array}$ & $\begin{array}{l}-0.098 \\
(.015)^{\star * *}\end{array}$ \\
\hline \multicolumn{7}{|l|}{ GxE } \\
\hline Compulsory*GRS & --- & --- & $\begin{array}{l}-0.031 \\
(.156)\end{array}$ & --- & --- & $\begin{array}{l}0.006 \\
(.013)\end{array}$ \\
\hline Post Compulsory*GRS & --- & --- & $\begin{array}{l}0.085 \\
(.148)\end{array}$ & --- & --- & $\begin{array}{l}0.006 \\
(.013)\end{array}$ \\
\hline University*GRS & --- & --- & $\begin{array}{l}-0.019 \\
(.148)\end{array}$ & --- & --- & $\begin{array}{l}0.007 \\
(.014)\end{array}$ \\
\hline $\mathrm{R}^{2}$ & 0.022 & 0.035 & 0.035 & 0.032 & 0.038 & 0.038 \\
\hline $\mathrm{N}$ & 8305 & 8305 & 8305 & 8305 & 8305 & 8305 \\
\hline \multicolumn{7}{|l|}{$\begin{array}{l}\text { Panel B: GRS based on } \\
\text { Locket et al. (2015) }\end{array}$} \\
\hline GRS & $\begin{array}{l}0.603 \\
(.052)^{\star \star *}\end{array}$ & $\begin{array}{l}0.598 \\
(.052)^{\star * *}\end{array}$ & $\begin{array}{l}0.647 \\
(.109)^{* * *}\end{array}$ & $\begin{array}{l}0.036 \\
(.005)^{\star \star \star}\end{array}$ & $\begin{array}{l}0.036 \\
(.005)^{\star \star \star}\end{array}$ & $\begin{array}{l}0.032 \\
(.004)^{\star \star *}\end{array}$ \\
\hline $\begin{array}{l}\text { Educational Attainment } \\
\text { Compulsory }\end{array}$ & -- & $\begin{array}{l}-0.533 \\
(.104)^{\star * *}\end{array}$ & $\begin{array}{l}-0.543 \\
(.164)^{* * *}\end{array}$ & --- & $\begin{array}{l}-0.018 \\
(.014)\end{array}$ & $\begin{array}{l}-0.018 \\
(.014)\end{array}$ \\
\hline
\end{tabular}




\begin{tabular}{|c|c|c|c|c|c|c|}
\hline Post Compulsory & --- & $\begin{array}{l}-0.701 \\
(.148)^{\star * *}\end{array}$ & $\begin{array}{l}-0.700 \\
(.149)^{\star * *}\end{array}$ & --- & $\begin{array}{l}-0.036 \\
(.014)^{\star *}\end{array}$ & $\begin{array}{l}-0.036 \\
(.013)^{\star *}\end{array}$ \\
\hline University & --- & $\begin{array}{l}-1.711 \\
(.101)^{* * *}\end{array}$ & $\begin{array}{l}-1.711 \\
(.161)^{\star * *}\end{array}$ & --- & $\begin{array}{l}-0.103 \\
(.015)^{\star * *}\end{array}$ & $\begin{array}{l}-0.103 \\
(.015)^{\star * *}\end{array}$ \\
\hline \multicolumn{7}{|l|}{ GxE } \\
\hline Compulsory*GRS & --- & --- & $\begin{array}{l}-0.096 \\
(.159)\end{array}$ & --- & --- & $\begin{array}{l}-0.010 \\
(.014)\end{array}$ \\
\hline Post Compulsory*GRS & --- & --- & $\begin{array}{l}-0.021 \\
(.142)\end{array}$ & --- & --- & $\begin{array}{l}0.011 \\
(.012)\end{array}$ \\
\hline University*GRS & --- & --- & $\begin{array}{l}-0.104 \\
(.151)\end{array}$ & --- & --- & $\begin{array}{l}0.012 \\
(.014)\end{array}$ \\
\hline $\mathrm{R}^{2}$ & 0.027 & 0.040 & 0.040 & 0.033 & 0.040 & 0.040 \\
\hline $\mathrm{N}$ & 8424 & 8424 & 8424 & 8305 & 8424 & 8424 \\
\hline
\end{tabular}

Notes: All models control for age, interview year and gender. Overweight equals 1 for those whose BMI is at least 25 . Very severely obese individuals $(B M I \geq 45)$ were excluded from the analyses. The omitted education reference category is less than compulsory education. The unweighted GRS has been standardized to have a mean of 0 and standard deviation of 1 . Heteroscedasticity-robust standard errors are reported in parentheses: *statistically significant at the 0.10 level; **at the 0.05 level; ${ }^{* * *}$ at the 0.01 level. 
Table 3: OLS estimates of main associations of education, genetic risk, and GXE interactions in the YFS

\begin{tabular}{|c|c|c|c|c|c|c|}
\hline & $\begin{array}{l}\text { BMI } \\
\text { (1) }\end{array}$ & $\begin{array}{l}\text { BMI } \\
(2)\end{array}$ & $\begin{array}{l}\text { BMI } \\
(3)\end{array}$ & $\begin{array}{l}\text { Overweight } \\
\text { (4) }\end{array}$ & $\begin{array}{l}\text { Overweight } \\
\text { (5) }\end{array}$ & $\begin{array}{l}\text { Overweight } \\
\text { (6) }\end{array}$ \\
\hline \multicolumn{7}{|l|}{ Genetics } \\
\hline GRS & $\begin{array}{l}0.589 \\
(.093)^{\star * *}\end{array}$ & $\begin{array}{l}0.573 \\
(.094)^{* * *}\end{array}$ & $\begin{array}{l}0.597 \\
(.127)^{\star \star \star}\end{array}$ & $\begin{array}{l}0.050 \\
(.011)^{* * *}\end{array}$ & $\begin{array}{l}0.049 \\
(.011)^{\star * *}\end{array}$ & $\begin{array}{l}0.050 \\
(.014)^{\star * *}\end{array}$ \\
\hline \multicolumn{7}{|c|}{ Educational Attainment } \\
\hline Post-secondary & --- & $\begin{array}{l}-0.171 \\
(.238)\end{array}$ & $\begin{array}{l}-0.163 \\
(.237)\end{array}$ & --- & $\begin{array}{l}0.005 \\
(.028)\end{array}$ & $\begin{array}{l}0.005 \\
(.028)\end{array}$ \\
\hline University & --- & $\begin{array}{l}-0.858 \\
(.220)^{\star * *}\end{array}$ & $\begin{array}{l}-0.848 \\
(.221)^{\star * *}\end{array}$ & --- & $\begin{array}{l}-0.066 \\
(.026)^{\star *}\end{array}$ & $\begin{array}{l}-0.066 \\
(.027)^{\star \star *}\end{array}$ \\
\hline \multicolumn{7}{|l|}{ GxE } \\
\hline Post-secondary ${ }^{*}$ GRS & --- & --- & $\begin{array}{l}-0.221 \\
(.223)\end{array}$ & --- & --- & $\begin{array}{l}-0.010 \\
(.028)\end{array}$ \\
\hline University*GRS & --- & --- & $\begin{array}{l}0.088 \\
(.242)\end{array}$ & --- & --- & $\begin{array}{l}0.004 \\
(.026)\end{array}$ \\
\hline $\mathrm{R}^{2}$ & 0.070 & 0.076 & 0.077 & 0.061 & 0.064 & 0.064 \\
\hline$N$ & 2062 & 2062 & 2062 & 2062 & 2062 & 2062 \\
\hline
\end{tabular}

Notes: All models control for birth month, birth year effects, and gender. Overweight equals one for those whose BMI was at least 25 in 2001 . Very severely obese individuals (BMI $\geq 45$ ) were excluded from the analyses. The omitted education category is compulsory or upper secondary education. The unweighted GRS has been standardized to have a mean of 0 and standard deviation of 1 . Heteroscedasticity-robust standard errors are reported in parentheses: *statistically significant at the 0.10 level; **at the 0.05 level; *** at the 0.01 level. 